\title{
Library Space Assessment Methods: Perspectives of New Information Professionals
}

\author{
Sheila Corrall \\ School of Computing and Information, University of Pittsburgh, \\ Pittsburgh, Pennsylvania, USA
}

\begin{abstract}
Purpose - The research explores the emerging specialty of learning space assessment with a focus on how new information professionals represented by graduate students in an academic libraries course defined quality criteria for library spaces and how they approached designing and conducting a one-shot multi-site space assessment project.

Design/methodology/approach - The instructor-investigator adopted a diachronic collective case study strategy, using documents generated by six cohorts over three academic years. The data included 180 online discussion posts, 97 individual site assessments, and 32 group project reports. Data were analyzed quantitatively and qualitatively to identify patterns and trends in student behaviour.

Findings - The analysis revealed a strong trend among students for creating their own evaluation frameworks in preference to reusing existing professional tools in their current form; the proportion of students who either developed their own criteria or combined existing criteria in new ways shifted from 40 percent to 80 percent in three years. Their approaches demonstrated willingness and ability to engage in independent and creative thinking, and readiness to explore interdisciplinary and international perspectives on space. They also displayed a commitment to accessible, flexible and adaptable user-centered design for active, collaborative learning, and to bringing a user perspective to their observations.

Originality/value - The focus on student-librarians provides a unique forward-looking perspective on the desirable qualities of next-generation learning spaces in academic libraries. The study also documents an unprecedented range of established and novel space evaluation frameworks and tools informed by different professional disciplines. The results should be of interest to LIS educators and practitioners.
\end{abstract}

Keywords Academic libraries, Evaluation frameworks, Learning spaces, Library assessment, Professional education, Service quality

Paper type Case study

\section{Introduction}

Assessment and space are among the most critical issues facing higher education institutions and their libraries in the 21st century. Assessment has been highlighted as a strategic concern by academic librarians and their professional associations, evidenced by initiatives such as the ACRL Assessment in Action program (Ackermann, 2015). Saunders (2016, pp. 1-2) observes that "Academic libraries are under enormous pressure to demonstrate their value through assessment" and "must engage in assessment". In addition, in parallel with significant growth in specialist assessment librarian positions (Oakleaf, 2013; Passoneau and Erickson, 2014), we find growing recognition that "Assessment cannot be seen as a separate 'management activity', but must be appreciated and valued by all members of the culture and assumed to be a part of their regular work" (Lakos and Phipps, 2004, p. 351); which is reflected in the competency statements of professional associations in our field (ALA, 2009; ALIA, 2014; CARL, 2010), and underlines the need for professional master's programs to prepare student librarians for 
assessment activities. However, a recent survey of American librarians with assessment responsibilities indicated that their professional education did not prepare them to perform assessment-related tasks (Fleming May and Mays, 2015).

Similarly, space/facilities planning features prominently in 60 of 63 academic library strategy documents reviewed by Saunders (2016), which in turn is reflected in the noticeable growth, development and diversification of methodologies, techniques and tools for conducting space evaluation and assessment research drawing on literature from both the traditional professional domains of librarianship and architecture, and emergent research communities specializing in green buildings, learning spaces and sedentary physiology (Crumpton and Crowe, 2009; DeClerq and Cranz, 2014; Felix and Brown, 2011; Gerke and Teeter, 2017; Germany, 2014; Lippincott and Duckett, 2013; Montgomery, 2017; Nitecki, 2011). A key trend here is the specific focus on assessing library spaces as learning environments (Felix and Brown, 2011; Lippincott and Duckett, 2013; Montgomery, 2017; Nitecki and Simpson, 2016). With space no longer viewed as just another part of the library infrastructure, but elevated to a mission-critical service, it makes sense to move space assessment from an occasional, limited activity to a core element of an ongoing assessment strategy (Gerke and Teeter, 2017). In addition, as Nitecki (2011, p. 27 ) suggests, assessing and evaluating the use of library space can provide additional meaningful insights into the present and future roles and purposes of an academic library. Hands-on evaluation projects with a focus on space have thus become an obvious vehicle for introducing new information professionals to the theory and practice of assessing service quality.

The purpose of the pedagogical research reported here was to investigate how new information professionals represented by six cohorts of master's students enrolled in a library and information science (LIS) program approached the task of assessing space in academic libraries. No prior studies of LIS students learning to conduct space assessments have been identified, and we anticipate the results of our study will be of interest to other LIS educators and practitioners in the field with an interest in assessing and evaluating library and learning spaces. The specific questions explored were how the MLIS students framed their space assessments, what evaluation criteria they chose to use, and whether they displayed particular characteristics associated with next-generation professionals. The paper first describes the data and methods used, next explains the space assessment task and its context, and then analyses and discusses the findings, using examples and extracts from student coursework to illustrate their approaches and methods. It is not possible to include comprehensive details here of the tools created by students to support their assessments; interested readers are invited to contact the author for additional information on material available.

Literature related to library space assessment is not reviewed separately but forms an integral part of the case study and is referenced throughout the research report. Readers interested in exploring the growing literature on the planning, design, development and assessment of library space can find fuller discussion in the recent book chapter by Diller (2017) or in the articles by Matthews and Walton (2014), Nitecki and Simpson (2016), and Turner et al. (2013).

\section{Data sources and methods}

The research was based on secondary data; i.e., data already existing as a byproduct of course delivery, rather than data generated specifically for the investigation. The data available included 180 online discussion posts, 97 individual assessment reports, 32 descriptions of evaluation criteria, and 32 group project reports. Following a preliminary small-scale "snapshot" study conducted after the first complete iteration of the course as a two-section onsite and online offering, which was presented at the 11th Northumbria International Conference on Performance Measurement in Libraries and Information Services held in Edinburgh, July 2015 
(Corrall, 2017), the present much larger study adopted a longitudinal or "diachronic" collective (multiple) case study strategy because the instructor was interested in not only analyzing within and across the different student groups, but also exploring whether student approaches to designing and conducting a one-shot space assessment were changing over time (Thomas, 2016, p. 114).

The student discussion and assignment submissions were examined, assessed and graded (as applicable) by the instructor during the terms when the course was taught in accordance with the course schedule, and then reviewed and analyzed together in the term following the third year of the dual-section course (i.e., in Spring 2017) for the purpose of the present study. The instructor monitored student progress through the different stages of the assignment, providing formative feedback on documents submitted and practical advice where needed to be sure their projects were manageable, but she did not seek to influence their basic approach to the assignment. Like the original study, the focus of the research project was to investigate how new information professionals, represented by a cohort of master's students taking a course on academic libraries as part of a professional education degree program, approached the task of designing and conducting a "one-shot" space assessment project.

In particular, the instructor-investigator was interested in examining across the six cohorts the independent thinking and creativity displayed by students in conducting their projects, which was among the criteria specified in the assignment rubric, but not specifically reflected in the grades awarded for the assignment, as the holistic grading method was used (i.e., all the criteria were taken into account, but one overall grade was assigned for each assessed submission, with no specific weightings attached to particular aspects or elements of the work). Creativity/innovation is often an assumed trait of millennial/next generation librarians, whose habits are reported to include "The tendency to think out of the box, try new things, work hard, be ambitious, work collaboratively, and not follow tradition solely because it is tradition" (Gordon, 2010, p. 394). Creative thinking is increasingly highlighted as an ability needed by graduate librarians to perform as innovators and change agents in the workplace (ALIA, 2014; CARL, 2009; Schwartz, 2016; SLA, 2016); creativity and innovation are also emphasized as core competencies in several chapters of The Expert Library (Crowe and Jaguszewski, 2010; Gendron, 2010; Lankes, 2010; Lehner, 2010), which is required reading for the course, and in the literature on competencies for assessment in libraries (Passoneau and Erickson, 2014).

\section{Case description and context}

The Academic Libraries course is delivered in 14 weekly learning modules in the Fall term. It is taught on campus in a traditional classroom setting and off campus via the University's Pitt Online platform. The two sections are managed separately, but students in both sections have access to the same learning content; both onsite and online students are required to use CourseWeb, a web-based course and learning management system (the University of Pittsburgh's implementation of BlackBoard) to engage with lecture materials, related readings, discussion forums and other learning resources. The only significant difference between the two sections is the mode of delivery for lectures, which are pre-recorded for the online students and available for viewing/listening at a time of their choice (together with full transcripts), instead of being delivered in real time; students in both sections have continuing access to lecture slides via CourseWeb for the duration of the course.

The topical modules are grouped into five units: Background and academic context; Facilities and resource management; Content and collection management; Service design and development; and Quality improvement and enhancement. Library as Space and Place is the first topic of Unit 2 (scheduled for the fourth week of term). The module consists of three required pre-lecture readings, a 15-20 minute lecture (15 slides), a set of video resources and a related online discussion forum (required for both online and onsite students) to be completed 
during Week 4, followed by a group space study project (supported by recommended additional readings and dedicated group discussion forums) to be completed in three stages, with assignments due by the ends of Weeks 5, 8 and 10. Staged assignments are a key feature of the course design that are used to help students plan and manage their time over the term, and to enable the instructor to track their progress and provide feedback on early submissions to inform their later work.

\section{Group project}

The group project requires students to conduct a multi-site case-study evaluation of library spaces in higher education institutions of their choice, in order to assess their fitness for purpose as 21 st century learning and research spaces. It asks students to think critically about the physical environment of academic libraries in relation to the missions and values of the libraries and their parent institutions (concepts explored in week 3 of the course), and is designed to enable them to learn about quality assessment in libraries, to gain experience in carrying out a small-scale evaluation study, and to develop their collaborative research, teamworking and report-writing skills. The assignment has group and individual components, which must be carried out in the prescribed sequence.

Stage 1 of the assignment requires each group collectively to review existing criteria for assessing/evaluating library space (drawing on material cited in the Module 4 lecture slides, items in the Module 4 reading list, and other related literature identified by group members). They then have to define the evaluation criteria they will use to assess the library spaces that will be the subjects of their study; they are advised they can adopt or adapt a ready-made set of criteria from the lecture slides or related literature (with appropriate attribution of the source), or create their own set of criteria, by either combining points from different sets of criteria, or developing their own new criteria. The key requirement here is that each group must discuss and agree the evaluation criteria together, and submit them to the instructor for approval/feedback, along with their chosen sites, before proceeding to their onsite assessments.

For stage 2, each group member must visit their chosen library site individually, evaluate the quality of the space using the previously agreed criteria, and then produce a concise summary of their assessment (around 500 words) structured around the criteria, identifying the strengths and weaknesses of the environment in meeting the needs of its user community. Even though this part of the project is carried out (and graded) individually, students are reminded that the quality of their individual assessments and the consistency of the approaches used are likely to affect the quality of their final group report. Students can choose how they conduct their assessments at a practical level, but are encouraged to discuss in their groups how they will collect evidence of good practice and poor provision (e.g., making notes, taking photos, and/or using checklists, forms, or other data collection instruments to record information at the site), bearing in mind that using a standard format will make it easier to compare their findings across sites at the next stage of the project.

The final stage of the project requires group members to share their individual reports, next carry out a cross-case analysis of their findings, looking for similarities and differences among the strengths and weaknesses, problems, and opportunities for improvement found, and then produce a collective synthesis of their findings, bringing together in a single narrative their overall evaluation of the spaces assessed, and their joint suggestions for changes to enhance the user experience, which might include general recommendations that apply to all sites assessed and/or specific recommendations on a site-by-site basis. While some ideas for space enhancements may come from good practices in one library that could be adopted or adapted by others, they are also expected to draw on published guidance and case studies, and 
reference academic/professional literature when explaining their criteria and discussing their findings, in order to relate their research to the wider professional context.

Their final group submission has to follow a prescribed structure, using headings typically found in social science research reports (Introduction, Methods, Results, Discussion, Conclusion and Recommendations), prefaced by an informative abstract, and supported by references and appendices, which must include the individual space assessments previously submitted. Providing a structure for their project report ensures students know what they need to cover and is a example of the cognitive scaffolding strategies used in the course in line with principles of transparency in teaching and learning (Cooper and Robinson, 2014; Rosenshine and Meister, 1992; Winkelmes, 2008; 2018); other examples of scaffolded learning and transparent teaching include discussing the goals and rationale for assignments, anticipating student errors (in assignment instructions), breaking down complex tasks into individual and sequential elements, using ungraded/low stakes assignments to get students started on a project, and providing formative feedback.

\section{Learning resources}

In preparation for the assignment and the related lecture in week 4, the students are expected to read Scott Carlson's frequently cited 2001 opinion piece on "The deserted library" in The Chronicle of Higher Education, Treadwell et al.'s (2012) account of the ethnographic methods used at a liberal arts campus to explore undergraduate and (post)graduate preferences for library space in the context of a facilities redesign project, and Lippincott and Duckett's (2013) article in Research Library Issues on connecting the assessment of library space to institutional goals for student learning. The week 4 lecture provides an overview of trends in library space, including developments such as green building design (Loder, 2010) and multipurpose facilities (Stewart, 2011), as well as looking at changes in the conceptualization of library space, from information commons to learning, knowledge, and research commons (Browndorf, 2014; Carroll, 2011; Turner et al., 2013; Watson, 2010).

The lecture concludes with a survey of established and emergent approaches to space assessment and evaluation, covering both evaluation criteria and assessment methods, drawing on literature from both the library and education domains, and also incorporating perspectives of professional architects. Examples include the treatment of space in the ACRL (2011) Standards for Libraries, ARL's LibQUAL+ survey instrument (Nitecki, 2011) and IFLA's Library Building Guidelines, represented by McDonald's (2006; 2007) update of Faulkner-Brown's "ten commandments"; checklists and frameworks drawn from case studies and opinion pieces (Daniels et al., 2010; Germany, 2014; Line, 2002; Schlipf, 2011); and Canadian liaison librarians Cunningham and Tabur's composite model mapping Kent and Myrick's (2003) four qualities of great public spaces to Maslow's (1943) hierarchy of needs. The Week 4 Reading List offered additional reviews, case studies, viewpoints, and tools, such as the IFLA post-occupancy evaluation questionnaire (Romero et al., 2013) to supplement the lecture references and support student research for Stage 1 of the assignment. The intention here was not to cover the topic comprehensively, but to illustrate the variety of quantitative and qualitative approaches available, ranging from simple checklists and frameworks to multi-/mixed-method and participatory designs.

To complement the lecture and provide a more explicit link between theory and real-world practice, students were required to view three short video presentations (3-6 minutes each) of new/renovated library spaces from around the world prior to posting to the Week 4 discussion forum on space as a service. This preliminary ungraded task was intended to help them get started on thinking critically about space as a resource and service, and about the desirable qualities of library spaces individually, before engaging in discussion of evaluation criteria within their groups. Students were asked to select three examples from a set of eight YouTube videos, 
to reflect on which space they felt worked best for learners at that institution, and then post comments to the forum, identifying their preferred space and the facilities or features that made it a good place to study. The videos represented a range of institutional settings, including examples of small, medium-sized and large universities, private and state-funded, situated from the East coast to the West of the US, with two examples from Europe (in Spain and the UK); they were deliberately chosen from around the world to reflect the stated intention of the course to provide a global perspective on academic librarianship and enable international comparisons.

\section{Case analysis and discussion}

The study population for the investigation reported here comprises 97 students formed into 32 groups from three onsite and three online sections of the course taught in Fall 2014, Fall 2015, and Fall 2016. Table 1 shows how participant numbers for the assessment project were distributed over the three years. It is worth noting that the students taking this course had widely varying levels of knowledge and experience of academic libraries, ranging from those whose knowledge was limited to their own use of libraries as undergraduates, through some with experience of employment as student assistants, to a few with many years of experience working in academic (or public) libraries as paraprofessionals. Generally the online students tend to have more experience than their onsite counterparts, with a substantial proportion working full-time in libraries while studying part-time. (The icebreaker forum used at the start of the course included questions about their prior library experience among the prompts used for students to introduce themselves to the course learning community.)

Table 1. Participant numbers for assessment project

\begin{tabular}{cccc}
\hline \multicolumn{2}{c}{ Course sections } & Students & Groups \\
\hline $2014 \quad$ Onsite & 14 & 5 \\
& Online & 6 & 2 \\
\multicolumn{2}{c}{ Subtotal } & 20 & 7 \\
$2015 \quad$ Onsite & 15 & 5 \\
& Online & 28 & 8 \\
\multicolumn{2}{c}{ Subtotal } & 43 & 13 \\
$2016 \quad$ Onsite & 13 & 5 \\
& Online & 21 & 7 \\
\multicolumn{2}{c}{ Subtotal } & 34 & 12 \\
\hline \multicolumn{2}{c}{ Grand Total } & 97 & 32 \\
\hline
\end{tabular}

\section{Discussion forum}

The low-stakes video assignment served its purpose of engaging students with the subject. Several students submitted two or more posts to the forum, with students in the online sections of the course typically being more active in their forums than students enrolled in the onsite sections (which was in line with their behavior throughout the course). Table 2 displays the number of posts to the Module 4 discussion forum for each cohort, and shows how the level of activity in both online and onsite cohorts increased noticeably over the period, but with a huge upsurge in activity for the 2016 online cohort, with a class of 21 students generating 79 posts. 
Table 2. Student posts to discussion forum

\begin{tabular}{cccc}
\hline Course sections & Students & Posts \\
\hline 2014 & Onsite & 14 & 16 \\
& Online & 6 & 8 \\
& Subtotal & 20 & 24 \\
2015 & Onsite & 15 & 13 \\
& Online & 28 & 43 \\
& Subtotal & 43 & 56 \\
& Onsite & 13 & 21 \\
& Online & 21 & 79 \\
& Subtotal & 34 & 100 \\
\hline Grand Total & 97 & 180 \\
\hline
\end{tabular}

Many students went way beyond the task requirements: several reported looking at more than the three videos required, and some viewed the complete set. Their comments evidenced genuine engagement with the subject matter, for example:

"I was curious about the different library spaces, so I watched all the videos" (Online student, 2016)

"I had a lot of fun with this assignment. I genuinely enjoyed looking at these gorgeous libraries" (Online student, 2016)

Students who had viewed the complete set of videos offered comments on general trends and common features identified; one student summarized what she had learned for her classmates:

"The similarities are striking. All of the libraries seek to meet student needs by providing a range of comfortable seating, spaces for collaborative group work, and spaces for quiet, individual study. All (or nearly all) also emphasize their open, airy spaces filled with light, and their cafes or coffee bars. All are committed to making technology accessible to students, and some, such as the Hunt Library at North Carolina State, have invested in lots of cutting-edge technology. Many librarians in the videos talked about the importance of getting past the old stereotypes of libraries as dusty, dark, quiet places where you're likely to be "shushed." Overall, the university libraries of the twentyfirst century are welcoming, comfortable, beautiful spaces, filled with light, and committed to helping students study and research independently and collaboratively." (Online student, 2016)

Even when they limited their viewing to three videos, students frequently offered general observations on commonalities before picking out specific points, e.g.,

"When looking at the different videos, I was struck by the similarities between the designs of all the buildings. While not exactly the same, I could definitely see the trend of large, open space, natural lighting and glass structure incorporated into each library." (Onsite student, 2015)

It was also encouraging to see the same student already starting to assess features of the space (in this case, the Main Library of the University of Edinburgh in the UK) against external standards (of the US Association of College \& Research Libraries), touching here on points 6.8 (consultation with users), 6.4 (intellectual commons), 6.5 (learning spaces), 6.2 (safe and secure), and 6.6 (physical connectivity). 
"Looking at the ACRL Standards for Libraries in Higher Education, there are a few key points that Edinburgh hit quite obviously. One of the first comments of the video is that the staff worked very closely with the students to create the new space. This consultation with users shows that the school was interested not only in updating the look of the library, but adapting it to meet growing student needs. It is also an intellectual commons space. The library seems to provide not only books, manuscripts and cultural artifacts for easy student use, but also group and private learning spaces, virtual material, and technology. It seems a safe, secure, clean location, with accessibility being a strong influence on the changes. By including the community to look at the archives, they are also a space that fosters connectivity with the outside world, not just the world within the university itself. The potential to facilitate learning is very high, with all of the points highlighted thus far." (Onsite student, 2015)

Several students also sought additional background information about the libraries or the context of space developments, for example by visiting their websites to find out more. One student phoned a featured library and talked with the User Experience Librarian (on a Saturday morning) to find out more about the role of librarians in the space (as only the director appeared in the video). Another shared what she had learned from looking for additional video resources:

"I also watched a TEDx talk by Tod Colegrove [science and engineering library director, University of Nevado, Reno]. He talked about the characteristics of a good library, which he compared to being like the Library of Alexandria. He described a good library as a place where resources are shared, a place where those values most important should be engagement, passion, community, belonging, creativity, etc." (Onsite student, 2015)

As the students selected different videos, it would be misleading to present the preferences expressed in their posts as rankings. However, it was interesting to look across the six cohorts and see the frequency and consistency of comments on four spaces that dominated the discussion transcripts, which included two significant physical upgrades and two brand new libraries: the Branford Price Millar Library of Portland State University, Oregon (upgrade); the Mary Idema Pew Library at Grand Valley State University, Michigan (new build); the Main Library of the University of Edinburgh, UK (upgrade); and the James B Hunt Jr. Library, North Carolina State University (new build). Observations collected from this preliminary assignment provided early signals of their professional/personal values in the context of library spaces serving student learning needs.

Portland State's Millar Library was continually applauded for its "commitments to meeting the diverse needs of students" (Online student, 2016), best illustrated by its family-friendly Study with Kids room for student parents, but also demonstrated in its tutoring/coaching facilities, technology-rich spaces, and equipment lending. Edinburgh featured particularly strongly in the 2016 forums, with students repeatedly commenting on how the library was "combining new needs with a sense of tradition" (Onsite student, 2016) and offering "a lot of study space without compromising their collection" (Onsite student, 2016), by opening up their special collections, as well as providing "big open areas with comfy chairs you can arrange as you like...'encouraging contemplation and collaboration' as the narrator suggests" (Onsite student, 2016). One student picked up on the change in attitude needed for the modern more user-centric model:

"my favorite part of the library's upgrade was the attitude of John Scally, Director of University Collections, who says that he wants to reverse the old stereotype of shushing librarians and stingy archivists... An adjustment of attitude is the key to making libraries more user friendly and bringing back their important heritage as centers of culture, and ultimately centers of community." (Online student, 2016)

Grand Valley State's Pew Library was similarly praised for its "inspirational" space, mixing the traditional with the modern, to meet the whole spectrum of educational, personal, 
technological and social needs of today's student, by providing "inventive, inviting group space in a learning commons model while also retaining many smaller rooms...for 'near silent, monkish' study" (Online student, 2016). Students also liked the learning/tutoring centre here, branded as the "Knowledge Market". North Carolina's Hunt Library was liked for its contemporary design and hi tech facilities, especially its bookbot delivery system - although several students were disturbed by the sparse provision of books on the open shelves.

\section{Evaluation criteria}

The overarching question for the investigation was How do MLIS students as novice information professionals approach library space assessment? More specifically, the study aimed to examine what evaluation criteria they chose and used, how they framed their assessments in terms of reference to established concepts, models, theories, methodologies, techniques and/or tools (e.g., adopting/adapting existing frameworks or developing new approaches), and to what extent they demonstrated independent thinking and/or creativity in the perspective offered. The small-scale pilot study of two cohorts taking the course in 2014 (20 students working in seven groups) found a variety of approaches, ranging from modified implementations and combinations of existing tools, to developing their own assessment categories and/or criteria, relying more on their personal experience and less on the professional literature (Corrall, 2017).

One notable finding from the 2014 cohorts was that the two online groups both searched for literature beyond the lecture material and course readings and chose the Australian Tool for Evaluation of Academic Library Space - TEALS (Abbasi et al., 2012; Elkadi and Abbasi, 2011; Horn et al., 2014) as the basis for their space assessments, both developing their own different modified (simplified) versions. In contrast, none of the five onsite groups cited literature beyond the lecture references and reading list, which prompted the question whether students taking the course online were more likely to engage in independent research/information-seeking (i.e., is the pattern of behaviour in 2014 a general characteristic, or a simple coincidence, acknowledging that a sample of two is too small to form a valid judgement).

Stage 1 of the formal assignment required each group to define group evaluation criteria for their individual site assessments, by adopting or adapting existing space assessment criteria or developing their own evaluation framework. Students were thus able to choose whether to follow established professional practice by reusing existing tools or to contribute to the development of practice by creating new tools or models. Figure 1 provides an overview of the strategies chosen by the 32 student groups by charting their approaches year-by-year on a fourpoint reuse/create continuum. The four-point scale reflects a spectrum of dependence on the literature representing professional thinking and practice, from being influenced at a specific level to being informed at a general level, acknowledging that all students had been exposed to related literature via the lecture slides irrespective of the extent to which they cited material in their submissions.

The results show how groups were positioned at all points of the spectrum during the period covered by the study, but the longitudinal analysis reveals significant progressive movement from heavy dependence on existing models in 2014 (when 4 of the 7 groups adopted or adapted existing criteria) to more independent and innovative thinking in 2016, when 10 of the 12 groups created a new model by either combining criteria in new ways or formulating their own criteria with only passing reference to the literature. Table 3 provides a more detailed mapping of their strategies, showing the breakdown by year, by group and by cohort (onsite and online). The results here show there were no significant differences between the strategies of the onsite and online cohorts, with the progressive shift from reuse to create over the three years clearly visible for both sets of groups. 


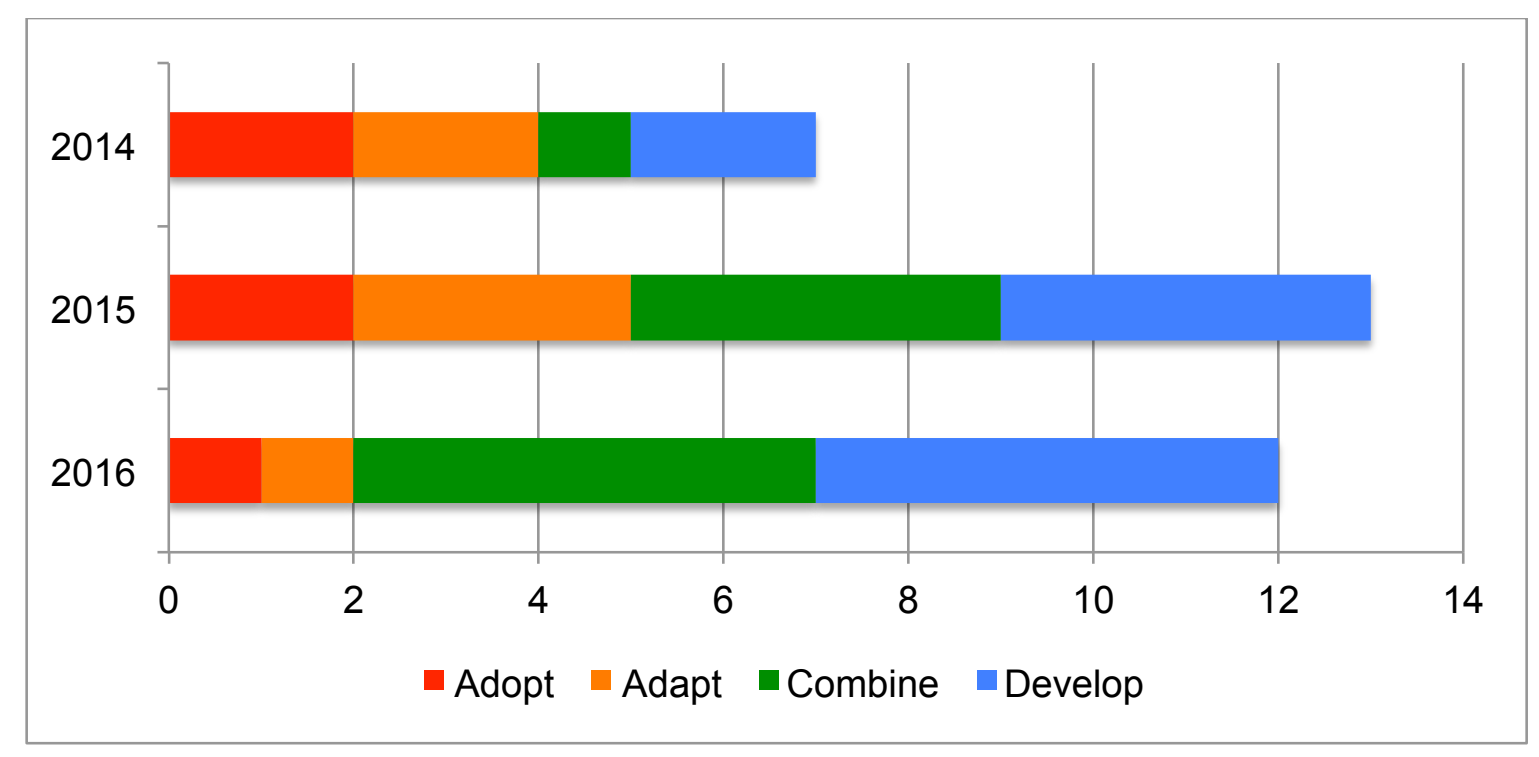

Figure 1. Student strategies for defining criteria

Table 3. Group decisions on evaluation criteria

\begin{tabular}{|c|c|c|c|c|c|}
\hline \multirow{2}{*}{\multicolumn{2}{|c|}{ Course sections }} & \multicolumn{2}{|c|}{ REUSE } & \multicolumn{2}{|c|}{ CREATE } \\
\hline & & \multirow{2}{*}{ Adopt } & \multirow{3}{*}{$\begin{array}{c}\text { Adapt } \\
\text { Group } 1 \\
\text { Group } 5\end{array}$} & \multirow{2}{*}{$\begin{array}{l}\text { Combine } \\
\text { Group } 4\end{array}$} & \multirow{2}{*}{$\begin{array}{l}\text { Develop } \\
\text { Group } 2 \\
\text { Group } 3\end{array}$} \\
\hline 2014 & Onsite & & & & \\
\hline & Online & $\begin{array}{l}\text { Group } 1 \\
\text { Group } 2\end{array}$ & & & \\
\hline & Subtotal & 2 & 2 & 1 & 2 \\
\hline \multirow[t]{3}{*}{2015} & Onsite & $\begin{array}{l}\text { Group } 3 \\
\text { Group } 5\end{array}$ & Group 2 & $\begin{array}{l}\text { Group } 1 \\
\text { Group } 4\end{array}$ & \\
\hline & Online & & $\begin{array}{l}\text { Group } 1 \\
\text { Group } 6\end{array}$ & $\begin{array}{l}\text { Group } 5 \\
\text { Group } 8\end{array}$ & $\begin{array}{l}\text { Group } 2 \\
\text { Group } 3 \\
\text { Group } 4 \\
\text { Group } 7\end{array}$ \\
\hline & Subtotal & 2 & 3 & 4 & 4 \\
\hline \multirow[t]{4}{*}{2016} & Onsite & Group 4 & Group 3 & $\begin{array}{l}\text { Group } 2 \\
\text { Group } 5\end{array}$ & Group 1 \\
\hline & Online & & & $\begin{array}{l}\text { Group } 4 \\
\text { Group } 5 \\
\text { Group } 6\end{array}$ & $\begin{array}{l}\text { Group } 1 \\
\text { Group } 2 \\
\text { Group } 3 \\
\text { Group } 7\end{array}$ \\
\hline & Subtotal & 1 & 1 & 5 & 5 \\
\hline & Grand Total & 5 & 6 & 10 & 11 \\
\hline
\end{tabular}




\section{Independent research}

Analysis of the literature used by students who adopted, adapted or combined established space evaluation criteria revealed an impressive level of independent research, defined here as searching for ideas and inspiration beyond the sources cited in the lecture slides or listed in the module readings. Fourteen distinct tools were used by the 21 groups who drew on existing documented models when choosing their criteria, of which seven tools were found as a result of independent information-seeking (i.e., neither the tools nor their source documents were included among the resources supplied by the instructor). Overall, of the 19 documents identified as sources for student reuse of existing space evaluation criteria, nine were items found by students through independent research. Table 4 displays the tools in descending order of popularity and also shows their domain (disciplinary roots), country of origin, corporate or personal authors, date of publication, and frequency of use by type of application. Asterisks in the table denote items identified independently by students.

\section{Professional authority}

The sources selected by student groups also indicate they were concerned about the professional authority of their chosen criteria, with six turning to ACRL's (2011) standards for their criteria, one using other material from ACRL developed in partnership with LLAMA (the management division of ALA), and seven using the Faulkner-Brown/McDonald (2006; 2007) "Ten Commandments", which are incorporated in the IFLA (International Federation of Library Associations) Library Buildings Guidelines (Latimer \& Niegaard, 2007). Interestingly, only two groups relied solely on ACRL material, with others pointing out areas where aspects of space they considered important were either missing or poorly represented in ACRL statements, notably accessibility and flexibility.

McDonald's (2006; 2007) "Ten Commandments" (also described as the "top ten qualities of good library space") have similar, arguably higher, professional authority (than ACRL). Originally developed in the 1970s by British architect Harry Faulkner-Brown, who designed many library buildings around the world in the second half of the 20th century, these desirable qualities have been continually reviewed and updated by British librarian Andrew McDonald, who is recognized internationally for his expertise in the design of library/learning spaces, and their incorporation into the IFLA Guidelines (Latimer \& Niegaard, 2007) gives them unique global status, as well as additional authority derived from their roots in the practice of a professional architect. Six of the seven groups using McDonald's qualities combined them with other tools: three with the ACRL (2011) standards, with one group also drawing on the Academic Library section of the Whole Building Design Guide, (NIBS, 2011) to strengthen coverage of key dimensions. Another group combined McDonald's qualities with selective use of questions from the IFLA post-occupancy evaluation questionnaire (Romero et al., 2013), which was used on its own by a different group. Two other groups used material from particular articles in the pre- and post-lecture readings to elaborate and focus their use of McDonald's (2006) qualities.

The Whole Building Design Guide (WBDG) is a web-based portal offering up-to-date information on building-related guidance, criteria, techniques and technologies from a "whole buildings" perspective, provided by the US National Institute of Building Sciences in conjunction with 25 federal agencies. It is a good example of the types of additional information resources sought and used by students to supplement material provided via the module lecture and course readings, and is another multi-professional tool informed by both architectural and engineering expertise. Other documents found by students through independent research included reports on the development and use of the Tool for Evaluation of Academic Library Space (TEALS), produced at Deakin University, Australia, by researchers from the School of Architecture and Building in collaboration with Deakin University Library (Abbasi et al., 2012; Elkadi \& Abbasi, 2011; Horn et al., 2014), which was used by two groups. 
Table 4. Evaluation tools used by students

\begin{tabular}{|c|c|c|c|c|c|c|c|}
\hline \multirow[b]{2}{*}{ Tool } & \multirow[b]{2}{*}{ Domain } & \multirow[b]{2}{*}{ Source } & \multirow[b]{2}{*}{ Reference(s) } & \multicolumn{4}{|c|}{ Frequency } \\
\hline & & & & Adopt & Adapt & Combine & Total \\
\hline $\begin{array}{l}\text { Ten Commandments/Top Ten } \\
\text { Qualities }\end{array}$ & $\begin{array}{l}\text { Architecture \& } \\
\text { Librarianship }\end{array}$ & UK & McDonald (2006; 2007) & & 1 & 6 & 7 \\
\hline $\begin{array}{l}\text { Standards for Libraries in Higher } \\
\text { Education: Space }\end{array}$ & Librarianship & USA & ACRL $(2011$, p. 12) & 1 & & 5 & 6 \\
\hline $\begin{array}{l}\text { Hierarchy of Learning Space } \\
\text { Attributes }\end{array}$ & $\begin{array}{l}\text { Architecture, Psychology } \\
\text { \& Librarianship }\end{array}$ & Canada & $\begin{array}{l}\text { Cunningham \& Tabur } \\
\text { (2012) }\end{array}$ & 1 & 1 & 1 & 3 \\
\hline $\begin{array}{l}\text { Tool for Evaluation of Academic } \\
\text { Library Space (TEALS) }\end{array}$ & $\begin{array}{l}\text { Architecture \& } \\
\text { Librarianship }\end{array}$ & Australia & $\begin{array}{l}\text { *Abbasi et al. (2012); } \\
\text { *Elkadi \& Abbasi }(2011) \text {; } \\
\text { *Horn et al. (2014) }\end{array}$ & 2 & & & 2 \\
\hline $\begin{array}{l}\text { IFLA Post-Occupancy Evaluation } \\
\text { (POE) Questionnaire }\end{array}$ & Librarianship & International & Romero et al. (2013) & & 1 & 1 & 2 \\
\hline Library Buildings: A User's Hate List & Librarianship & UK & Line (2002, pp. 86-87) & & 1 & 1 & 2 \\
\hline $\begin{array}{l}\text { Technology, Architecture and } \\
\text { Furniture (TAF) Model }\end{array}$ & $\begin{array}{l}\text { Education/Learning } \\
\text { Spaces }\end{array}$ & Australia & Germany $(2014$, p. 272$)$ & & & 2 & 2 \\
\hline Assessment Plan: Guiding Questions & Librarianship & USA & $\begin{array}{l}\text { Lippincott \& Duckett } \\
(2013, \text { pp. 14-15) }\end{array}$ & & & 2 & 2 \\
\hline $\begin{array}{l}\text { Academic Library Building Design: } \\
\text { Resources for Planning: Standards } \\
\text { and Guidelines }\end{array}$ & Librarianship & USA & *ACRL \& LLAMA (2016) & & 1 & & 1 \\
\hline $\begin{array}{l}\text { Whole Building Design Guide: } \\
\text { Academic Library }\end{array}$ & $\begin{array}{l}\text { Architecture \& } \\
\text { Engineering }\end{array}$ & USA & *NIBS (2017) & & 1 & & 1 \\
\hline POE Questions & Architecture \& Healthcare & USA & $\begin{array}{l}{ }^{*} \text { DeClerq \& Cranz } \\
(2014)\end{array}$ & & 1 & & 1 \\
\hline POE Space Attributes & Architecture & Netherlands & ${ }^{*}$ Cha \& Kim (2015) & & & 1 & 1 \\
\hline FIT SPACES & Learning Spaces & Australia & $\begin{array}{l}\text { *Andrews \& Munnerley } \\
(2013)\end{array}$ & & & 1 & 1 \\
\hline $\begin{array}{l}\text { User Satisfaction Statements: } \\
\text { Infrastructure/Place/Space }\end{array}$ & Librarianship & Malaysia & *Kassim (2009) & 1 & & & 1 \\
\hline
\end{tabular}


Examples of other architect-designed tools found through independent research included instruments for post-occupancy evaluation of libraries developed by architecture researchers based in departments of architecture at the University of California Berkeley (DeClerq \& Cranz, 2014), where the Center for the Built Environment is recognized as a centre of expertise in POE; and at the University of Cambridge and City University of Hong Kong, whose tool had been applied at Eindhoven University of Technology in the Netherlands (Cha \& Kim, 2015). Taken together these examples indicate students were able to recognize library space design as both an area of practice with a multidisciplinary knowledge base and a global phenomenon, and show how they were prepared to be outward-looking and to venture beyond their own professional domain and learn from international experts and practitioners in other countries.

\section{International perspectives}

Continuing the international influences, another group found a more general library performance evaluation tool in a Malaysian journal, which had been developed by LIS faculty and used in a public university library (Kassim, 2009), from which they extracted the 20 survey items related to library space, and then added two items to strengthen technology assessment. Interestingly, none of the groups explicitly referenced ARL's LibQUAL+ tool as a source for their criteria, despite the fact that the five LibQUAL+ statements on the "library as place" ("space that inspires study and learning", "quiet space for individual activities", "a comfortable and inviting location", "a getaway for study, learning or research", and "community space for group learning and group study") featured in both the Module 4 lecture and the related readings (e.g., Nitecki, 2011, p. 41).

Other international library influences included the published "user's hate list" provided by the former director general of The British Library, Maurice Line (2002, pp. 86-87), which was used by two onsite groups (in 2015 and 2016) and cited as an influence by another online group (in 2015); and the Hierarchy of Learning Space Attributes developed by two reference and liaison librarians at the University of Toronto (Cunningham and Tabur, 2012), which was used by two onsite groups in 2014, and one in 2015 (and cited by two online groups in 2016). The list and hierarchy were both presented to students in the Module 4 lecture, but adapted by the students for use in their evaluation criteria.

However, the learning spaces community in Australia, which is generally credited with the first use of the term "next generation learning space" at a colloquium hosted by the University of Queensland in 2007 (Fraser, 2014, p. xv), proved a particularly rich source of inspiration, especially for students in the online sections. In addition to the architect/librarian-developed TEALS tool from Deakin University used by the two 2014 online groups, two 2016 online groups used the Technology, Architecture and Furniture (TAF) model from Queensland (a statesponsored education sector initiative), which categorizes 19 elements of a learning space that should be evaluated under four headings: Environmental, Functional, Emotional, and Pedagogical (Germany, 2014, p. 272), while one of the 2016 onsite groups used the nineelement FIT SPACES framework (Andrews and Munnerly, 2013). In contrast to the 2014 groups using TEALS, these three 2016 groups all combined their Australian tools with criteria from other Anglo/American sources, namely ARL (Lippincott and Duckett, 2013), ACRL (2011) and McDonald's (2006) qualities, to bring a truly global perspective to the task of space assessment.

Overall, although around three-quarters of the additional literature referenced by students (i.e., items cited in their reports that were not provided in the course readings) had a US focus in contrast to the instructor's reading list, which was evenly balanced between US literature and material from other countries - if we look instead at the published tools reused by students (listed in Table 4), we find nine of the 14 tools (i.e., nearly two-thirds) came from outside the US. The instructor had continually emphasized to students the use of academic and professional literature and other resources from around the world to provide a global perspective on 
academic libraries and enable international comparisons, including an upfront statement on the point in the course syllabus, which is in line with the University of Pittsburgh's (2012) public acknowledgment that an international perspective was critical to its mission in education, research and service to society. It was therefore good to see these new-generation academic librarians responding so positively to the opportunities to enrich their thinking and practice by looking beyond examples from the US.

\section{Creative thinking}

Table 3 shows 11 of the 32 groups (i.e., around one-third) were positioned in the fourth column representing the least dependence on existing professional frameworks, and 21 of the 32 (nearly two-thirds) placed in either column 4 or column 3 , which together represent the independent/creative thinking part of the reuse-create continuum described earlier. The data in both Table 3 and Figure 1 also show an interesting shift over time, with the independent thinkers moving from a minority position (just over 40 percent) in year 1, through a small majority (more than 60 percent) in year 2 to a very large majority (over 80 percent) in year 3 . The pattern identified here tends to support literature on next-generation/millennial librarians which highlights out-of-the-box thinking and doing things differently (Gordon, 2010), and also suggests the majority of recent Pitt academic librarianship graduates are on track to develop the competencies in creativity and innovation specified in The Expert Library and in the assessment librarian literature (Crowe and Jaguszewski, 2010; Gendron, 2010; Lankes, 2010; Lehner, 2010; Passoneau and Erickson, 2014).

Turning to specifics, students who developed their own evaluation frameworks all produced a set of critical factors to evaluate, variously described as broad criteria, evaluative questions or assessment categories, ranging from 3 to 10 in number across the 11 groups, with 6 being the median value, but 5 and 7 emerging as the most frequent values (each found three times).

Figure 2 displays a word cloud based on the terms used by students for these basic categories, and shows that the terms and concepts represented were similar to points found in existing published frameworks.

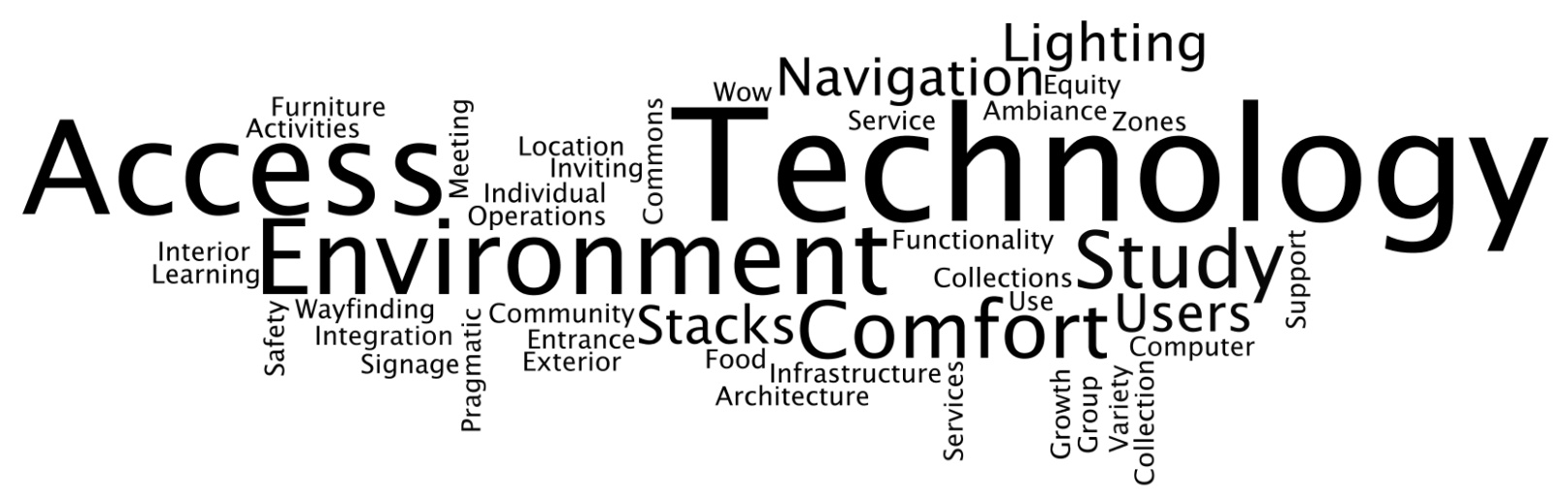

Figure 2. Assessment categories chosen by students

Indeed 7 of the 11 groups stated explicitly how their choice of criteria had been influenced by the literature, using phrases such as "informed by" and "based on". Some groups named sources for specific concepts or factors incorporated in their criteria, such as McDonald's (2006, 2007) "wow" factor, and his emphasis on space design being flexible and adaptable to allow for physical expansion and renovation; others also acknowledged authors whose work they used to elaborate particular categories into sub-categories: for example, Online Group 3 (2015) cited Jackson and Hahn (2011) as the source for the development of their "sense of place" category. This group was among several who turned their categories into questions, e.g., 
(1) Is the space inviting?

(2) What are the study spaces like?

(3) What are the non-study spaces like?

(4) Is it easy to find spaces within the library?

(5) What is the infrastructure like?

(6) What is the sense of community in the library?

(7) Is there possibility for expansion?

(8) What is the overall sense of place?

Other influences mentioned included the lecture presentation, professional standards, a video, group discussion, independent research, and personal experience, opinion, or judgement. Several groups indicated they started with their own ideas and then looked to literature to substantiate, elaborate or frame their thinking: for example, one group originally came up with a list of questions arranged under just two headings, then used a modified version of the observation template provided in the NCSU Learning Space Toolkit (which they found through independent research) to structure their assessment around five categories. Others started with the literature and then worked creatively, reporting that they crafted, rather than selected their criteria:

"... our group decided to create our own set of evaluative questions. As such, Group Four's library space evaluation criteria were crafted (rather than selected) on the basis of our readings and collective experiences as pertain to the significant elements that contribute to the fulfillment of the purposes of a library's spaces." (Online group 4, 2015)

Alternatively, they selected literature for collaborative review, and "pulled together" their criteria through creative group conversation:

"We selected nine peer-reviewed articles on library space assessment and evaluation to establish our own assessment model... Criteria [were] pulled together from the following sources, as well as group conversation." (Online group 7, 2016)

Another online group from the same cohort was impressively systematic and rigorous in developing and reporting their approach, describing how individual findings from the literature were shared and discussed via the group's BlackBoard discussion board, and explaining the principles and values that influenced their thinking and research, which supplemented the course readings with additional information, advice and guidance from diverse sources (including the Access Advocates consultancy website, Library Assessment Conference proceedings, and a library space assessment rubric developed by a MLS student at another university on a field placement in an institutional learning technology unit, as well as the ACRL/LLAMA resource). Online Group Two (2016) cited Felix and Brown's (2011) discussion of active learning environments as a key influence on their criteria, along with Cunningham and Tabur's (2012) four characteristics of learning space attributes, but also explained how their reading influenced both their choice of method for data collection (observation) and their decisions on the timing of their site visits for peak hours, citing evidence from the literature to justify concentrating their assessments on the first four days of the week, between the hours of 2 and 5 PM (Crumpton and Crowe, 2009).

Other distinctive dimensions of this group's approach were the title they gave their report, The Roots of Knowledge: Multi-Site Assessment through the Same Lens; their determination of an expected standard for their spaces (measured against 24 criteria using a 5-point scale) and an "acceptable score band" (an average score in the range 3.5 to 4.5); and their creation of a comprehensive analytic rubric to support data collection, analysis and interpretation. The Roots of Knowledge Academic Library Space Assessment Rubric extended to 7 pages (US letter size, 
landscape orientation), with the first page used to record basic data about each site and also first impressions of the library in a standard format, in addition to the name of the institution, type of space, and date and time of assessment. Figure 3 reproduces the preliminary section of the instrument used for basic data about each library, showing how the students used a mix of quantitative and qualitative indicators in their evaluation, and also how the items selected and descriptors chosen for this opening section start to communicate their personal and professional values and beliefs about what a library should offer and how it should feel.

\begin{tabular}{|c|c|c|c|c|c|}
\hline \multicolumn{6}{|c|}{ Circle the word that describes your feelings when entering the library: } \\
\hline Overwhelmed & Distracted & Bored & Focused & Scholarly & Energized \\
\hline \multicolumn{6}{|c|}{ The last library renovation was: } \\
\hline $\begin{array}{l}\text { Within the } \\
\text { past - }\end{array}$ & $0-5$ years & $6-10$ years & $11-15$ years & $16-20$ years & Unknown \\
\hline \multicolumn{6}{|c|}{ Lockers and Cubbies: } \\
\hline & None & & $\begin{array}{l}\text { Very small section } \\
\text { of cubbies/lockers }\end{array}$ & & $\begin{array}{c}\text { Cubbies, lockers and } \\
\text { coat area }\end{array}$ \\
\hline \multicolumn{6}{|c|}{ Reference Desk: } \\
\hline & $\begin{array}{l}\text { One main } \\
\text { reference } \\
\text { desk }\end{array}$ & & $\begin{array}{c}\text { Two reference } \\
\text { desks }\end{array}$ & & $\begin{array}{l}\text { Reference located } \\
\text { strategically } \\
\text { throughout library }\end{array}$ \\
\hline \multicolumn{6}{|c|}{ Circulation Desk: } \\
\hline & $\begin{array}{l}\text { Desk cannot } \\
\text { be found from } \\
\text { entrance }\end{array}$ & $\begin{array}{l}\text { Desk located } \\
\text { far from } \\
\text { entrance and } \\
\text { poorly marked }\end{array}$ & $\begin{array}{l}\text { Desk near to } \\
\text { entrance but poorly } \\
\text { marked }\end{array}$ & $\begin{array}{l}\text { Desk clearly } \\
\text { visible upon } \\
\text { entrance but } \\
\text { poorly marked }\end{array}$ & $\begin{array}{l}\text { Desk clearly visible } \\
\text { upon entrance to the } \\
\text { library and clearly } \\
\text { marked }\end{array}$ \\
\hline \multicolumn{6}{|c|}{ Activity in the Library } \\
\hline Empty & Light & Moderate & Heavy & Crowded & Overwhelming \\
\hline
\end{tabular}

Figure 3. Basic data about the library

The four main sections of the rubric (headed Environment, Technology, Space, and Access) are presented in an 8-column table, showing the criterion in the first column, verbal descriptions for the scores 1-5 in columns 2-6 (which are nicely colour-coded, a space for the score awarded in column 7 and a larger space for the assessor to justify the score in column 8 . There is additional space at the end of each section to record and comment on the subtotal score for the section, and similarly at the end of the rubric, where there is also a final section asking the assessor to "Describe your willingness to study in this library and likelihood you will recommend to other students", demonstrating how the group had internalized the key message from a book chapter assigned as one of the pre-lecture readings, "Seeing ourselves as others see us: library spaces through student eyes" (Treadwell et al., 2012, p. 127). The rubric also provides visible evidence of the amount of effort, level of thought and attention to detail given by the students to the project; the text compiled to describe the five levels for their 24 assessment criteria amounted to nearly 2,000 words. Table 5 reproduces an extract from the Access section of the instrument, giving additional insights into the values of these students, by revealing their position on contemporary hot topics for many academic libraries, namely the browsability of printed book collections and the professional staffing of reference desks. 


\begin{tabular}{|c|c|c|c|c|c|c|c|}
\hline Criterion & 1 & 2 & 3 & 4 & 5 & Score & Justification \\
\hline \multicolumn{8}{|l|}{ Access- } \\
\hline $\begin{array}{l}\text { Open } \\
\text { Stacks }\end{array}$ & $\begin{array}{c}\text { No library } \\
\text { shelves } \\
\text { with books. }\end{array}$ & $\begin{array}{l}\text { Very limited } \\
\text { number of } \\
\text { outdated } \\
\text { books on } \\
\text { shelves. } \\
\text { Located in } \\
\text { a remote } \\
\text { location. }\end{array}$ & $\begin{array}{l}\text { Adequate } \\
\text { number of } \\
\text { books on } \\
\text { shelves, } \\
\text { located in a } \\
\text { low traffic } \\
\text { area. } \\
\text { Not } \\
\text { conducive to } \\
\text { "serendipitous } \\
\text { discovery". }\end{array}$ & $\begin{array}{l}\text { Mixture of } \\
\text { older and } \\
\text { newer books } \\
\text { on shelves, } \\
\text { space for } \\
\text { "serendipitous } \\
\text { discovery", } \\
\text { located in a } \\
\text { low traffic } \\
\text { area. }\end{array}$ & $\begin{array}{c}\text { Nice } \\
\text { collection of } \\
\text { books with } \\
\text { adequate } \\
\text { space for } \\
\text { "serendipitous } \\
\text { discovery", } \\
\text { located in a } \\
\text { visible/high } \\
\text { traffic area. }\end{array}$ & & \\
\hline Staff & $\begin{array}{l}\text { No visible } \\
\text { professional } \\
\text { library staff. } \\
\text { Student } \\
\text { workers not } \\
\text { adequately } \\
\text { trained. }\end{array}$ & $\begin{array}{l}\text { No visible } \\
\text { professional } \\
\text { library staff. } \\
\text { Student } \\
\text { workers } \\
\text { adequately } \\
\text { trained to } \\
\text { answer } \\
\text { most } \\
\text { questions. }\end{array}$ & $\begin{array}{c}\text { One } \\
\text { professional } \\
\text { library staff } \\
\text { member } \\
\text { supported by } \\
\text { trained } \\
\text { student } \\
\text { workers. }\end{array}$ & $\begin{array}{l}\text { Professional } \\
\text { library staff, } \\
\text { not easily } \\
\text { accessible. } \\
\text { Trained } \\
\text { student } \\
\text { workers, } \\
\text { easily } \\
\text { accessible } \\
\text { throughout } \\
\text { the library. }\end{array}$ & $\begin{array}{l}\text { Mixture of } \\
\text { professional } \\
\text { library staff } \\
\text { and trained } \\
\text { student } \\
\text { workers. } \\
\text { All easily } \\
\text { accessible } \\
\text { throughout } \\
\text { the library. }\end{array}$ & & \\
\hline
\end{tabular}

Figure 4. Extract from space assessment rubric

While the rubric developed by Online Group 2 from the 2016 cohort was the most extensive example of a student-created instrument, the work of Online Group 4 from the previous year was equally sophisticated. They created a six-page instrument:

"a space assessment tool comprised of criteria-based questions organized into seven appraisal areas, and cross-segmented by scoring values to form a matrix...intended to support uniformity in assessment results to facilitate cross-site comparisons". (Online Group 4, 2015)

However, their approach differed from Online Group 2 (2016) in that after identifying space attributes they considered "essential for users" (e.g., adequate signage, lighting), they based their main assessment categories (described as appraisal areas) on distinct physical areas of the library (e.g., entrance, individual study, group study, book stacks and computer work areas); they turned their assessment criteria (based on the space attributes identified) into questions, arranged under their appraisal areas as headings, noting that many space attribute questions (e.g., Light adequate?) were common to several sections of their matrix. Like the 2016 group, they recognized the importance of viewing their spaces from a user perspective, but cited different items from the module readings as guiding them towards "first-person questions":

"their emphasis on individual use prompted us to shape some of our attribute evaluations into firstperson questions, such as 'I feel safe here' and 'I enjoy being here' (Montgomery 2014; Lippincott and Duckett 2013). Our intent was to be mindful to evaluate our sites as users, not as detached observers." (Online Group 4, 2015)

Their matrix also used a 5-point scale with an extra column for Evaluator's notes/Comments (and a column to record a score as Not Applicable), but used generic verbal descriptors (Worst/Unacceptable, Below average/Marginally acceptable, Average/Acceptable, Above average/Better than acceptable, and Best/Exceptionally good) instead of specific descriptions 
for each element to be assessed (105 altogether). However, recognizing the ambiguity and subjectivity of some terms, this group produced definitions to clarify the meanings of 13 words from their matrix (e.g., adequate, comfortable, inviting, sufficient, suitable).

Another novel, original feature of their report was the provision of a new assessment metric, the Destination Place Affinity, or DPA quotient, "developed to measure library spaces' suitability for learning", which "quantifies 21st century learning suitability". DPA is calculated as the sum of points scored on the matrix questionnaire tool, divided by the total possible points, and then multiplied by 100 to obtain a simple percentage:

\section{Points Scored / Total Points x 100 = Destination Place Affinity (\%) (Online Group 4, 2015)}

\section{Innovative combinations}

As shown in Table 3, ten groups were placed in the third column (Combine), representing nearly one-third of the total groups, but with a noticeable shift towards this position in 2015 and 2016. Groups in this category generally demonstrated skills in both creative thinking in the way they combined and adapted elements from existing criteria and critical appraisal, evidenced in their careful and systematic identification of strengths and weaknesses in their source material. Seven of the ten groups combined points from two sources, while three drew on three sources to compile their evaluation criteria; in addition, one of the groups that used two sources in effect incorporated three perspectives in their model, as they mapped the ACRL (2011) standards to Cunningham and Tabur's (2012) hierarchy, itself a composite model combining perspectives from architecture and psychology to define desirable attributes of learning spaces.

Five groups here used the ACRL (2011) Standards, but chose to supplement them with other tools because of perceived shortcomings: two groups drew on McDonald's $(2006 ; 2007)$ set of desirable qualities to give due emphasis to flexibility and adaptability, interactivity and collaboration, and accessibility or other environmental concerns, with one group also drawing on the US NIBS Whole Building Design Guide. Two more groups used other tools - the Australian TAF model (Germany, 2014) and the learning attributes hierarchy (Cunningham and Tabur, 2012) to help contextualize their assessments as learning space evaluations; and the fifth group combined the Standards with Line's (2002) checklist and McDonald's (2006; 2007) "wow" factor. Another group primarily used McDonald's (2006; 2007) qualities, but drew on Jackson and Hahn's (2011) notion of the library as "sacred space" to elaborate and flesh out the meaning of his wow/"oomph" factor. Two more groups used McDonald's (2006; 2007) qualities as their basic framework: one used them to select a manageable set of points from the 230-question IFLA POE instrument (Romero et al., 2013); another mapped them to a modified version of the Australian FIT SPACES model (Andrews and Munnerly, 2013), using the latter to place their study in a learning context.

Overall, the groups in the Combine category (like those in the Develop category) showed a readiness to think creatively and do things differently: they were prepared to challenge the status quo by pointing out what they perceived as gaps or weaknesses in existing professional standards and frameworks, and come up with novel approaches to devising criteria. Two groups who mapped existing library-based criteria to learning space frameworks also followed through their creative efforts to produce new visual models to present and share their evaluation criteria: Onsite Group 4 (2014) adapted an existing pyramid diagram provided by Cunningham and Tabur (2012), by substituting their own statements and annotations for each level of the Hierarchy, based on points from the ACRL (2011) Standards; in contrast, Onsite Group 5 (2016) created their own relationship diagram, to show how McDonald's (2006) Ten Commandments related to and complemented the qualities incorporated in Andrews and Munnerley's (2013, slide 9) FIT SPACES model of learning spaces (previously presented as a list of points). Figure 
4 displays their composite model; note that the Group included McDonald"s (2006) "wow" factor in their assessment, but did as a separate entity.

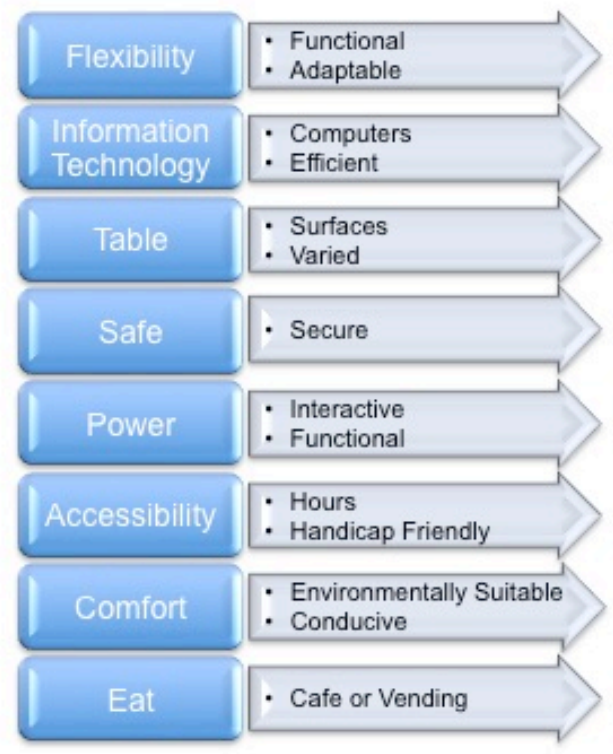

Figure 5. FITSPACE and the Ten Commandments

\section{Assessment techniques}

Most of the 11 groups placed in the Develop category used a two-level approach similar to those outlined for Online Group 4 (2015) and Online Group 2 (2016), breaking down their main categories into sub-categories representing specific items or particular aspects to be evaluated. Like the number of main categories, the total number of sub-categories varied, from 17 to the 105 items already mentioned (though the latter included many duplicate items). The average ratio of sub-categories to categories here was around five to one, using the median value here (on account of the extreme outlier). These groups also typically constructed a matrix or table to record their data, using either a five-point scale with an additional column for comments; or, alternatively, a simpler binary model, recording Yes/No, with additional headings for Strengths and Weaknesses. One group (Online Group 3, 2015) used a ten-point scale to rate their sites against their eight categories/questions, which enabled differences between sites to be brought out more clearly; their categories were supported by sub-categories and subsidiary questions, but the rating was applied only to the primary questions. Three of the 11 groups used only one level of assessment categories, with no quantification.

In most cases, quantification was used just as a quick and easy way to assess the facilities on the ground in the limited time available for a one-shot evaluation. Although the two groups described above carried through their quantitative data into summative scores that featured in their final group project reports, the majority used minimal quantitative data in their final reports, apart from providing their completed individual site assessments as appendices (which they were required to do). Online Group 3 (2015) produced a multi-coloured clustered column chart comparing the ratings for their three libraries for their eight categories, but placed it in an appendix and simply referred to it in their report. Generally, the groups favoured a more qualitative style of evaluation, although they were evidently concerned to use methods and procedures that were objective and consistent to make reliable assessments and comparisons. For example, Online Group 3 (2015) used the Recommendations section of their report to go beyond the expected suggestion for improving the spaces studied, by reflecting on their 
methodology and suggesting how it could be improved, apparently leaning more towards the rubric-based approach adopted by Online Group 2 (2016):

\footnotetext{
"The authors feel that the list of criteria was complete. However, they recommend modifying the list to make sure that individual assessments are coded uniformly. There is an inherent element of subjectivity that impacts assessment scoring. More concrete examples of elements that would generate a score of 10 , or 5 , or 1 , would lead to more objectivity. This in turn would make future space assessment more reliable and provide more concrete opportunities for comparing and contrasting different library spaces." (Online Group 3, 2015)
}

Groups who chose to Adopt, Adapt or Combine existing evaluation criteria used similar practical techniques and procedures to carry out their assessments. Observation was not surprisingly the primary method chosen by all student groups for collecting evidence for their snapshot assessments, as other methods typically used for regular library space assessments, such as survey questionnaires, focus groups, design workshops, reflective diaries, and other ethnographic and participatory techniques would not have been feasible in the time available (Andrews et al., 2016; Crumpton and Crowe, 2009; Germany, 2014; Nitecki, 2011). Students typically supplemented their note-taking by taking photographs as both reminders of their observations and for incorporation in their reports as illustrative evidence. In addition, some students also collected existing documents, such as floor plans and other institutional documentation, and a few also included such material in the appendices of their reports.

Moreover, as noted above, many groups explicitly strove to work at the participative end of the detached/engaged observer spectrum in an effort to see their spaces from a user viewpoint, often citing literature from the course readings to support this position (Line, 2001; Lippincott and Duckett 2013; Montgomery 2014; Treadwell et al., 2012), as they recognized the value of "Seeing through the eyes of students" (Bedwell and Banks, 2013, p. 1), which was naturally easier for student-librarians who were concurrently researchers and learners than it would be for seasoned practitioners. As Bedwell and Banks (2013, p. 1) have shown, where students observe other students, "Their complete membership in the culture under observation permits unobtrusive access and a richness of collected data that is enhanced by observer insight into student life", although here, as library science students (and, in many cases, part-time library workers), they obviously had to try to set aside their developing professional know-how to adopted this stance authentically and successfully.

\section{Conclusion}

Our investigation of methods and techniques used by student-librarians to design and conduct one-shot multi-site space assessments identified an array of influences on their approaches, including literature from diverse professional domains drawn from many different countries, which confirmed the emergent field of learning space assessment as a global concern and a specialty increasingly shaped by multidisciplinary expertise and interdisciplinary thinking. The students who adopted, adapted or combined existing frameworks used 14 distinct tools, informed by the knowledge base of six disciplines individually or collectively (architecture, education, engineering, healthcare, librarianship and psychology), originating in six countries (Australia, Canada, Malaysia, Netherlands, UK and USA) or as an international initiative. Around one-third of the 32 groups were positioned at the extreme end of the reuse-create spectrum of interaction with current professional practice, having opted to develop their own evaluation criteria, making little or no use of established assessment models, although their work generally showed familiarity with the terms and concepts of the field.

Additional analysis of the group reports revealed several interesting patterns in the data, providing evidence of independent and creative thinking among students placed in the Adopt, Adapt, and Combine categories (as well as the groups in the Develop category). Seven of the 
14 tools and nine of the 19 source documents used by students to frame their evaluations were not referenced in the course materials, but found through independent research. In addition, four of these seven tools originated outside the USA (having been developed in Australia, Malaysia and the Netherlands); a readiness to acknowledge the value of global perspectives was also evident in the tools selected by students from the course readings, where five out of seven resources again originated outside the US. Students located in both the Develop and Combine categories demonstrated creative thinking in various ways. In some cases, the creativity was particularly evident in the presentation of their framework (e.g., the creation of visual models, development of an analytic rubric, or use of colour coding); in others, it was shown in the content of their reports (e.g., the definition of key terms to strengthen consistency and objectivity of their assessments, and the development of a new assessment metric).

Overall, it was interesting to see the shift over time in the positioning of students on the reuse-create continuum, moving from a majority of groups placed in the Adopt or Adapt columns in the first year to two-thirds placed in the Combine or Develop columns in year three, which tends to support the characterization of next-generation librarians as out-of-the-box thinkers, who are prepared to look critically at established practices. It is important to note here that the students also displayed a strong commitment to the profession and its traditional values, which was evident in the frequent citation of sources representing professional authority, including statements from ACRL and IFLA; but they also showed awareness of contemporary values promoted in library literature (such as accessibility, flexibility/adaptability, user-centered design and active learning), and they were ready to contribute to professional thinking and practice by articulating alternative or additional assessment criteria they considered important.

\section{Acknowledgement}

The author gratefully acknowledges the contribution of the MLIS students who participated in the group multi-site space study as part of their Academic Libraries course in 2014, 2015 and 2016, whose ideas and insights have enriched the research reported here.

\section{References}

Abbasi, N., Elkadi, H., Horn, A. and Owen, S. (2012), "Transforming academic library spaces: an evaluation study of Deakin University Library at the Melbourne Burwood campus using TEALS", in ALIA 2012: Discovery: Proceedings of the 2012 Australian Library and Information Association Biennial Conference, July 10-13, 2012, Sydney, Australia, pp. 113.

Ackermann, E. (2015), Putting Assessment into Action: Selected Projects from the First Cohort of the Assessment in Action Grant, Association of College and Research Libraries, Chicago, IL.

ACRL (2011, October), Standards for Libraries in Higher Education, Association of College and Research Libraries, American Library Association, Chicago, available at http://www.ala.org/acrl/standards/standardslibraries (accessed 30 June 2017).

ACRL and LLAMA (2016), "Standards and guidelines" (rev. ed.), in Academic Library Building Design: Resources for Planning, Association of College \& Research Libraries and Library Leadership and Management Association, American Library Association, Chicago, IL, available at http://acrl.libguides.com/buildingresources (accessed 30 June 2017).

ALA (2009), ALA's Core Competences of Librarianship, American Library Association, Chicago, $\mathrm{IL}$, available at http://www.ala.org/educationcareers/careers/corecomp/corecompetences (accessed 30 June 2017). 
ALIA (2014, December 09), The Library and Information Sector: Core Knowledge, Skills and Attributes, Australian Library and Information Association, Deakin, Australia, available at https://www.alia.org.au/about-alia/policies-standards-and-guidelines/library-andinformation-sector-core-knowledge-skills-and-attributes (accessed 30 June 2017)

Andrews, T. and Munnerley, D. (2013), "Evaluation of learning spaces", presented at ACODE 61 Workshop: Learning Spaces, March 21, 2013, Sydney, Australia, Australasian Council on Open, Distance and e-Learning (ACODE), available at http://www.acode.edu.au/pluginfile.php/406/mod_resource/content/1/Acode_Evaluating Learning_Spaces.pdf (accessed 30 June 2017).

Andrews, C., Wright, S.E. and Raskin, H. (2016), "Library learning spaces: investigating libraries and investing in student feedback", Journal of Library Administration Vol. 56 No. 6, pp. 647-672, doi:10.1080/01930826.2015.1105556.

Bedwell, L. and Banks, C.S. (2013), "Seeing through the eyes of students: participant observation in an academic library", Partnership: The Canadian Journal of Library and Information Practice and Research Vol. 8 No. 1, pp. 1-17, DOI: 10.21083/partnership.v8i1.2502, available at https://journal.lib.uoguelph.ca/index.php/perj/article/view/2502/2905 (accessed 30 June 2017).

Browndorf, M. (2014), "Student library ownership and building the communicative commons", Journal of Library Administration Vol. 54 No. 2, pp. 77-93, DOI: 10.1080/01930826.2014.903364.

CARL (2010), Core Competencies for 21st Century CARL Librarians, Canadian Association of Research Libraries/ L'Association des bibliothèques de recherche du Canada, Ottawa, Canada, available at http://www.carl-abrc.ca/uploads/pdfs/core_comp_profile-e.pdf (accessed 30 June 2017).

Carlson, S. (2001, November 16), "The deserted library", The Chronicle of Higher Education Vol. 48 No. 12, p. A35.

Carroll, D. (2011), "Fostering a community of scholars at the University of Warwick: the Wolfson Research Exchange", New Review of Academic Librarianship Vol. 17 No. 1, pp. 78-95, DOI: $10.1080 / 13614533.2011 .547820$.

Cha, S.H. and Kim, T.W. (2015). "What matters for students' use of physical library space?", Journal of Academic Librarianship Vol. 41 No. 3, pp. 274-279, DOI: 10.1016/j.acalib.2015.03.014.

Colegrove, T. (2013, June 10), Libraries of the Future: Tod Colegrove at TEDxReno [Video file], available at https://youtu.be/RvE0gHhK3ss (accessed 30 June 2017).

Cooper, J.L. and Robinson, P. (2014), "Using classroom assessment and cognitive scaffolding to enhance the power of small-group learning", Journal on Excellence in College Teaching Vol. 25 No. 3\&4, pp. 149-161.

Corrall, S. (2017), "Library space assessment: a review and professional education case study", Performance Measurement and Metrics Vol. 18 No. 2, pp. 127-136, DOI: 10.1108/PMM05-2017-0015.

Crowe, S. H. and Jaguszewski, J.M. (2010). "Preparing our librarians for the future: identifying and assessing core competencies at the University of Minnesota Libraries", in Walter, S. and Williams, K. (Eds.), The Expert Library: Staffing, Sustaining, and Advancing the Academic Library in the 21st Century, Association of College \& Research Libraries, Chicago, IL, pp. 127-157. 
Crumpton, M. and Crowe, K. (2009), "Using evidence for library space planning”, in Hiller, S., Justh, K., Kyrillidou, M. and Self, J. (Eds.), Building Effective, Sustainable, Practical Assessment: Proceedings of the 2008 Library Assessment Conference, August 4-7, 2008, Seattle, WA, Association of Research Libraries, Washington, DC, pp. 51-64, available at http://libraryassessment.org/bm doc/proceedings-lac-2008.pdf (accessed 28 April 2017).

Cunningham, H.V. and Tabur, S. (2012), "Learning space attributes: reflections on academic library design and its use", Journal of Learning Spaces Vol. 1 No. 2, available at http://www.partnershipsjournal.org/index.php/jls/article/view/392/287 (accessed 30 June 2017).

Daniels, W., Darch, C. and de Jager, K. (2010), "The Research Commons: a new creature in the library", Performance Measurement and Metrics Vol. 11 No. 2, pp. 116-130, DOI: 10.1108/14678041011064043.

DeClerq, C.P. and Cranz, G. (2014), "Moving beyond seating-centered learning environments: opportunities and challenges identified in a POE of a campus library", Journal of Academic Librarianship, Vol. 40 No. 6, pp. 574-584, DOI: 10.1016/j.acalib.2014.08.005.

Diller, K.R. (2017), Space assessment: an interdisciplinary look at past and present studies", in Montgomery, S.E. (Ed.), Assessing Library Space for Learning, Rowman \& Littlefield, Lanham, MD, pp. 3-20.

Elkadi, H. and Abbasi, N. (2011), "Development of a tool for evaluation of academic library spaces (TEALS)", in Positive Futures for Higher Education: Connections, Communities and Criticality: 2011 Society for Research into Higher Education Annual Research Conference, December 7-9, 2011, Newport, Wales, available at http://www.srhe.ac.uk/conference2011/abstracts/0242.pdf (accessed 30 June 2017).

Felix, E. and Brown, M. (2011), "The case for a learning space performance rating system", Journal of Learning Spaces Vol. 1 No. 1, available at http://www.partnershipsjournal.org/index.php/jls/article/view/287/137 (accessed June 30, 2017).

Fleming-May, R. and Mays, R. (2015), “Assessing librarians' preparation for assessment: development and preliminary findings from a survey", poster presented at 11th Northumbria International Conference on Performance Measurement in Libraries and Information Services, Edinburgh, UK, July 20-22, 2015.

Fraser, K. (2014), "Introduction", in Fraser, K. (Ed.), The Future of Learning and Teaching in Next Generation Learning Spaces, Emerald, Bingley, UK, pp. xv-xxiii.

Gendron, H. (2010), "Put the pieces together and you get the perfect academic librarian... or do you? What competency standards tell us about academic librarianship in the 21st century", in Walter, S. and Williams, K. (Eds.), The Expert Library: Staffing, Sustaining, and Advancing the Academic Library in the 21st Century, Association of College \& Research Libraries, Chicago, IL, pp. 76-92.

Gerke, J. and Teeter, K. (2017), "Counting heads: building space assessment into your library assessment plan", in ACRL 2017: At the Helm, Leading Transformation, March 22-25, 2017, Baltimore, MD, pp. 152-159, available at http://www.ala.org/acrl/conferences/acrl2017/papers (accessed 30 June 2017).

Germany, L. (2014), "Learning space evaluations - timing, team, techniques”, in Fraser, K. (Ed.), The Future of Learning and Teaching in Next Generation Learning Spaces, Emerald, Bingley, UK, pp. 267-288.

Gordon, S. (2010), "Once you get them, how do you keep them? Millennial librarians at work", New Library World Vol. 111 no. 9/10, pp. 391-398, DOI: 10.1108/03074801011089314. 
Horn, A., Lingham, B. and Owen, S. (2014), "Library learning spaces in the digital age", in Measures for Success: Library Resources and Effectiveness under Scrutiny: Proceedings of the 35th Annual IATUL Conference, June 2-5, 2014, Espoo, Finland, available at http://docs.lib.purdue.edu/iatul/2014/libraryspace/2/ (accessed 30 June 2017).

Jackson, H.L. and Hahn, T.B. (2011), "Serving higher education's highest goals: assessment of the academic library as place”. College \& Research Libraries Vol. 72 No. 5, pp. 428-442, doi:10.5860/crl-123, available at http://crl.acrl.org/index.php/crl/article/view/16178 (accessed 30 June 2017).

Kassim, K.A. (2009), "Evaluating users' satisfaction on academic library performance", Malaysian Journal of Library \& Information Science Vol. 14 No. 2, pp. 101-115, available at http://majlis.fsktm.um.edu.my (accessed 30 June 2017).

Kent, F. and Myrick, P. (2003), "How to become a great public space", American Libraries Vol. 34 No. 4, pp. 72-74, 76.

Lakos, A. and Phipps, S. (2004), "Creating a culture of assessment: a catalyst for organizational change", portal: Libraries and the Academy Vol. 4 No. 3, pp. 345-361, DOI: 10.1353/pla.2004.0052.

Lankes, R. D. (2010). "Innovators wanted: no experience necessary", in Walter, S. and Williams, K. (Eds.), The Expert Library: Staffing, Sustaining, and Advancing the Academic Library in the 21st Century, Association of College \& Research Libraries, Chicago, IL, pp. 52-75.

Latimer, K. and Niegaard, H. (Eds.), IFLA Library Building Guidelines: Developments and Reflections, K.G. Saur, Munich, Germany.

Lehner, J. (2010), "New challenges in academic library personnel selection", in Walter, S. and Williams, K. (Eds.), The Expert Library: Staffing, Sustaining, and Advancing the Academic Library in the 21st Century, Association of College \& Research Libraries, Chicago, IL, pp. 30-51.

Line, M.B. (2002), “Library buildings: a user's viewpoint”, LIBER Quarterly Vol. 12 No. 1, pp. 7387, available at http://doi.org/10.18352/lq.7669 (accessed 30 June 2017).

Lippincott, J.K. and Duckett, K. (2013), "Library space assessment: focusing on learning", Research Library Issues, No. 284, pp. 12-21, available at http://publications.arl.org/rli284/12 (accessed 30 June 2017).

Loder, M. W. (2010), "Libraries with a future: how are academic library usage and green demands changing building designs?", College \& Research Libraries, Vol. 71 No. 4, pp. 348-360, DOI: 10.5860/crl-37r1, available at http://crl.acrl.org/index.php/crl/article/view/16094/17540 (accessed 30 June 2017).

Maslow, A.H. (1943), "A theory of human motivation", Psychological Review Vol. 50 No. 4, pp. 370-396, DOI: 10.1037/h0054346.

Matthews, G. and Walton, G. (2014), "Strategic development of university library space", New Library World Vol. 115 No. 5/6, pp. 237-249, DOI: 10.1108/NLW-05-2014-0062.

McDonald, A. (2006), "The ten commandments revisited: the qualities of good library space", LIBER Quarterly Vol. 16 No. 2, available at http://doi.org/10.18352/lq.7840 (accessed 30 June 2017).

McDonald, A. (2007), "The top ten qualities of good library space”, in Latimer, K. and Niegaard, H. (Eds.), IFLA Library Building Guidelines: Developments and Reflections, K.G. Saur, Munich, Germany, pp. 13-29.

Montgomery, S.E. (2014), "Library space assessment: user learning behaviors in the library", Journal of Academic Librarianship Vol. 40 No. 1, pp. 70-75, doi:10.1016/j.acalib.2013.11.003.

Montgomery, S.E. (Ed.) (2017), Assessing Library Space for Learning, Rowman \& Littlefield, Lanham, MD. 
NCSU (n.d.), Learning Space Toolkit, North Carolina State University, Raleigh, NC, available at https://learningspacetoolkit.org (accessed 27 April 2017).

NIBS (2017), Whole Building Design Guide: Academic Library (rev. ed.), National Institute of Building Sciences, Washington, DC, available at http://www.wbdg.org/buildingtypes/libraries/academic-library (accessed 30 June 2017).

Nitecki, D.A. (2011), "Space assessment as a venue for defining the academic library", Library Quarterly Vol. 81 No. 1, pp. 27-59, DOI: 10.1086.657446.

Nitecki, D.A. and Simpson, K. (2016), "Communicating the library as a learning environment", Journal of Learning Spaces Vol. 5 No. 2, pp. 39-52. Available at http://libjournal.uncg.edu/jls/article/view/1318/969 (accessed 2 November 2017).

Oakleaf, M. (2013), "Building the assessment librarian guildhall: criteria and skills for quality assessment", Journal of Academic Librarianship, Vol. 39 No. 2, pp. 126-128. DOI: 10.1016/j.acalib.2013.02.004.

Passonneau, S. and Erickson, S. (2014), "Core competencies for assessment in libraries: a review and analysis of job postings", Library Leadership \& Management Vol. 28 No. 4, pp. 1-19. available at https://journals.tdl.org/llm/index.php/llm/article/view/7080/6308 (accessed 30 June 2017).

Romero, S., Latimer, K., Sommer, D., Scherer, J., Clevström, S., Edebro-Sikström, I., Eigenbrodt, O. and Bostick, S. (2013), Questionnaire on Post-Occupancy Evaluation of Library Buildings, IFLA Library Buildings and Equipment Section, The Hague, Netherlands, available at http://www.ifla.org/publications/questionnaire-on-postoccupancy-evaluation-of-library-buildings (accessed 30 June 2017).

Rosenshine, B. and Meister, C. (1992), "The use of scaffolds for teaching higher-level cognitive strategies", Educational Leadership Vol. 49 No. 7, pp. 26-33.

Saunders, L. (2015), “Academic libraries' strategic plans: top trends and under-recognized areas", Journal of Academic Librarianship Vol. 41 No. 3, pp. 285-291. DOI: 10.1016/j.acalib.2015.03.011.

Schlipf, F. (2011), "The dark side of library architecture: the persistence of dysfunctional designs", Library Trends Vol. 60 No. 1, pp. 227-255, DOI: 10.1353/lib.2011.0034, available at https://www.ideals.illinois.edu/handle/2142/31870 (accessed 30 June 2017).

Schwartz, M. (2016), "Top skills for tomorrow's librarians", Library Journal Vol. 141 No. 4, pp. 38-39. available at http://lj.libraryjournal.com/2016/03/careers/top-skills-for-tomorrowslibrarians-careers-2016/ (accessed 30 June 2017).

SLA (2016, April 13), Competencies for Information Professionals (rev. ed.), available at https://www.sla.org/about-sla/competencies/ (accessed 30 June 2017).

Stewart, C. (2011), "Building measurements: assessing success of the library's changing physical space", Journal of Academic Librarianship Vol. 37 No. 6, pp. 539-541, DOI: 10.1016/j.acalib.2011.09.002.

Thomas, G. (2016), How To Do Your Case Study: A Guide for Students and Researchers (2nd ed.). Sage, London.

Treadwell, J., Binder, A. and Tagge, N. (2012), "Seeing ourselves as others see us: library spaces through student eyes", in Duke, L.M. and Asher, A.D. (Eds.), College Libraries and Student Culture: What We Now Know, ALA Publishing, Chicago, IL, pp. 127-142.

Turner, A., Welch, B. and Reynolds, S. (2013), "Learning spaces in academic libraries - a review of the evolving trends", Australian Academic \& Research Libraries Vol. 44 No. 4, pp. 226-234, DOI: 10.1080/00048623.2013.857383.

University of Pittsburgh (2012), Using a University-Wide Culture of Assessment for Continuous Improvement: A Self-Study Submitted to the Middle States Commission on Higher Education, available at http://www.middlestates.pitt.edu/self-study-2012 (accessed 30 June 2017). 
Watson, L. (2010), "The future of the library as a place of learning: a personal perspective", New Review of Academic Librarianship Vol. 16 No. 1, pp. 45-56, DOI: 10.1080/13614530903574637.

Winkelmes, M.-A. (2008), "Building assignments that teach", Essays in Teaching Excellence: Toward the Best in the Academy Vol. 19 No. 8, [pp. 1-7], available at http://podnetwork.org/content/uploads/V19-N8-Winkelmes.pdf (accessed 30 June 2017).

Winkelmes, M.-A. (2013), "Transparency in teaching: faculty share data and improve students' learning", Liberal Education Vol. 99 No. 2, pp. 48-55, available at http://www.aacu.org/publications-research/periodicals/transparency-teaching-facultyshare-data-and-improve-students (accessed 30 June 2017).

\section{About the author}

Sheila Corrall is a Professor in the Department of Information Culture and Data Stewardship at the University of Pittsburgh School of Computing and Information, where she teaches courses on Academic Libraries and Research Methods, and an introductory doctoral seminar on Academic Culture and Practice. She was previously Head of the Information School at the University of Sheffield and also served as director of library and information services at three universities in the UK. Her research interests include scholarly communication and the open movement, collection development in the digital world, reflective practice and professional competence, and intellectual capital perspectives on libraries. Sheila Corrall can be contacted at: scorrall@pitt.edu 